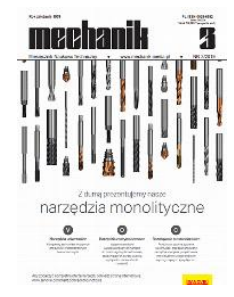

\author{
How to cite this article: \\ Author: Tomasz Ryba \\ Title of article: „Overview of the rubber belts tension test methods in the close transport conveyors” \\ Mechanik, No. 3 (2019) \\ DOI: https://doi.org/10.17814/mechanik.2019.3.28
}

\title{
Overview of the rubber belts tension test methods in the close transport conveyors
}

\author{
TOMASZ RYBA * \\ * Mgr inż. Tomasz Ryba, ryba2104@op.pl - UTH im. K. Pułaskiego w Radomiu, Radom, Polska
}

The review of existing solution and the proposal of the test equipment for belts tension detection on the conveyor in the real time is presented. Application of strain gauges made it possible to obtain the data, which would enable to make proper work condition diagnosis and to adapt the process to requirements of the Industry 4.0.

KEYWORDS: rubber belt, Industry 4.0, strain gauges

\section{Introduction}

In recent years, belt conveyors have gained a new meaning in industry - both due to the wide application possibilities and as a result of developing innovative constructions using modern materials and production technologies. The use of conveyors in transport systems includes the effect of the need to reduce transport costs, implemented so far with the use of wheeled vehicles, and the operating costs of transport systems, but in such a way as to ensure their sufficiently high reliability and durability [1].

The use of modern manufacturing technologies and global surveillance programs is the hallmark of the industrial revolution called Industry 4.0. The assumption is a system of perfectly harmonized elements, in which machine tools, technological machines, robots and people together create a new production environment [2]. Its essential element is the Internet of Things (IoT), which is to take control of the production infrastructure and monitor the costs of its maintenance and performance. Implementation of such systems increases efficiency and energy savings. However, to meet the requirements of Industry 4.0, global access to data at every stage of production is necessary.

In order to adapt belt conveyors, that are an important element of the production cycle, to these requirements, literature was analyzed and an innovative solution was proposed.

\section{Classic solutions}

Typical methods of testing the belt tension have been described, among others, in the works of Gładysewicz [3] and Kulinowski [4]. These publications contain standard mathematical calculations enabling the selection of belts.

In order to select the belt, the material and core structure should be considered after checking the preselected nominal strength and choosing the thickness and material of the protective covers. One of the most important aspects is technical and economic factor. According to Gładysewicz, an important point of the design calculations is the selection of the nominal strength $K_{\mathrm{n}}$ and determination of forces in the belt. The nominal strength of the fabric core belt is checked according to the following inequality [3]:

where:

$$
K_{\mathrm{n}} \geq \frac{(S r) \max }{100 \cdot B} \cdot k_{\mathrm{e}} \cdot k_{\mathrm{b}}
$$

$K_{\mathrm{n}}$ - nominal strength (belt strength class) $[\mathrm{kN} / \mathrm{m}$ or N/mm];

$B$ - belt width [m]; 
(Sr)max - maximum force in the belt during start-up [N];

$k_{\mathrm{e}}$ - safety factor taking into account operating conditions;

$k_{\mathrm{b}}$ - stress concentration coefficient in the joint.

Kulinowski also shows mathematical methods for determining, among others, friction coupling and forces occurring in the belt. It takes into account the requirements of DIN 22101, which refers to factors affecting the strength of the belt [4]. Unfortunately, these works do not contain any recommendations regarding diagnostics of conveyor belt operation in a real time.

\section{Review of research directions}

In the spirit of the assumptions of Industry 4.0, publications from recent years draw attention to the general technical aspects of belt conveyors, as well as construction, design and operational details. A lot of work was devoted to the problems of connecting conveyor belts and belts themselves. Due to the nature of this paper, only a few major studies are discussed.

Zur and Hardygóra, based on the analysis of the impact of belt damages and the connection structure on the belt strength, recognized the joint area as the weakest link of the belt working on the conveyor, the strength parameters of which depend on the reliable operation of the entire transport device [5]. Their work shows that the strength of the belt will be that of the weakest joint.

Currently, three types of conveyor belt joining are most commonly used on the market:

- bonding,

- vulcanization,

- mechanical connection using various types of fittings.

Research works described by Madziarz [6] concerned the analysis of the impact of the structure and technology of fabric jointing of belts on their strength. The cause of damage to the belt connections working in industrial conditions in specific conveyors was sought.

It was found that $25 \%$ of the recorded damage to fabric belt joints is delamination resulting from inadequate joint adhesion. Damages were also the result of manufacturing defects, including cuts in spacers and inaccurate preparation of weld surfaces. A certain relationship was found between the strength of the joints and many execution errors difficult to avoid [6].

Madziarz attempted to develop a mathematical model for the connection of a large spacer belt and to verify the results obtained in elasto-optical tests. An important point of research was the creation of connection models, in which the rubber layer was replaced with an optically sensitive material, due to which it was possible to directly record the disturbance of the tangential stress distribution in the interlayer.

Results of the described tests were characterized by high inaccuracy, resulting from the difference in the mechanical properties of elasto-optical material and interlayer rubber. Other factors increasing errors are small thickness of the tested connection models, small range of applied loads and specificity of elasto-optical tests. Difficulties have been demonstrated in relation to the calculated values of notch coefficients to the magnitude of stress occurring in real conditions [6].

Similar issues were raised in the work of Błażej [7], who points out that the basic criterion in the design of belt conveyors is the appropriate selection of the belt and strength value of the connection. Shear stress in the interlayer rubber was adopted as the basic parameter deciding about the strength of the large-pile fabric-rubber belt connection. The author attempted to identify the stresses in the adhesive joint and to determine the relationship between this size and mechanical properties of the belt core. The form strain angle was described as the distribution of elongation and stress in the adhesive joint [7].

Mazurkiewicz has developed one of the modern methods of monitoring the condition of the conveyor. He stated that it is possible to monitor the elongation of joints during conveyor operation with the simultaneous determination of the critical value of elongation, when it ceases to be a dynamic elongation associated with changing operating conditions, and becomes a value indicating a close connection break [1].

With a view to verifying its assumptions, Mazurkiewicz designed and constructed a system monitoring the elongation of conveyor belt joints in industrial conditions (fig. 1).

The system is used to automatically monitor the condition of adhesive joints to detect changes in relation to each individual joint that may lead to its breaking.

Methods of monitoring the conveyors operation include the use of steel cables in a belt, controlled by magnetic sensors. The measurement takes place directly on the conveyor. It provides information about the magnetic field being recorded. Any deviations of this field from the adopted value testify to irregularities in the structure of the belt [8]. 


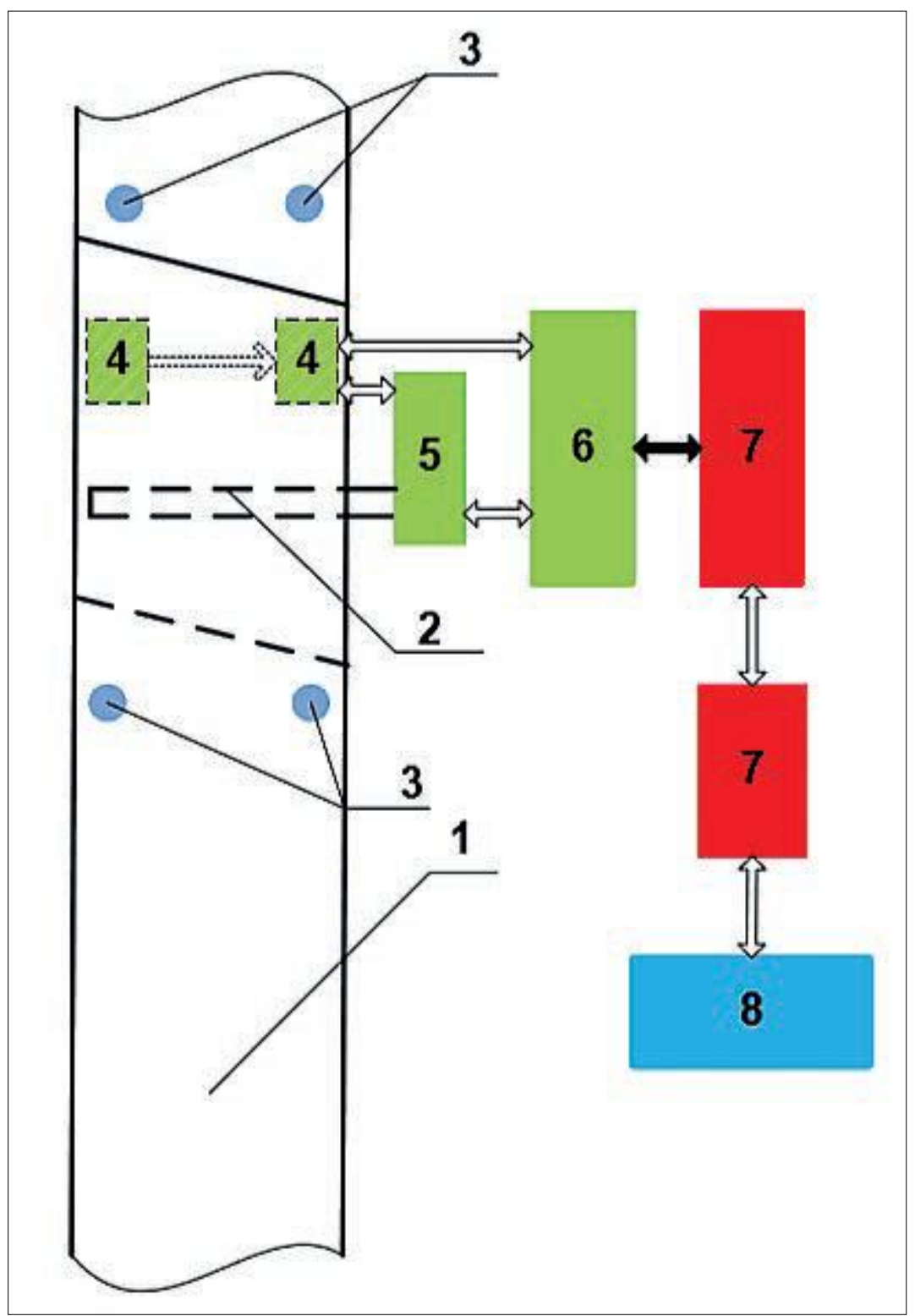

Fig. 1. Schematic diagram of the monitoring system: 1 - conveyor belt,

2 - connector area, 3 - marker, 4 - sensor, 5 - measuring device, 6 - microprocessor controller, 7 - digital data transmission system, 8 - computer system [1 ]

There are also publications on methods of radiographic diagnosis of fabric and steel straps (searching for cracks and corroded areas), as well as ultrasonic diagnostics to detect belt cuts [9].

One of the ways to control the condition of the belt in a real time is to install special sensors monitoring the wear or damage based on the operation of transponders. However, this system has many limitations.

It only allows to assess the abrasive wear of the belt or its tear and requires the construction of a special transceiver system. Data obtained from the detection system based on sensors located in the belt are of low quality and can be misinterpreted, and the cost of building the station is high.

The importance of a proper belt operation for the conveyor structure was emphasized in many scientific papers. It is important to select the operating parameters so that the belt is operated in optimal conditions, taking into account its technical parameters. However, to determine these conditions, one needs to know the properties of the belt.

Attempts to learn the characteristics of the conveyor belt work were presented by Fedorko and Ivančo [10]. They developed a 3D model of the belt and subjected it to stresses resulting from the conveyor geometry. They received a graphic distribution of forces and stresses along the entire length of the belt (fig. 2). Due to 
such analyses, it is possible to determine, where the concentration of excessive forces and stresses occurs, and take this information into account when designing the conveyor geometry.

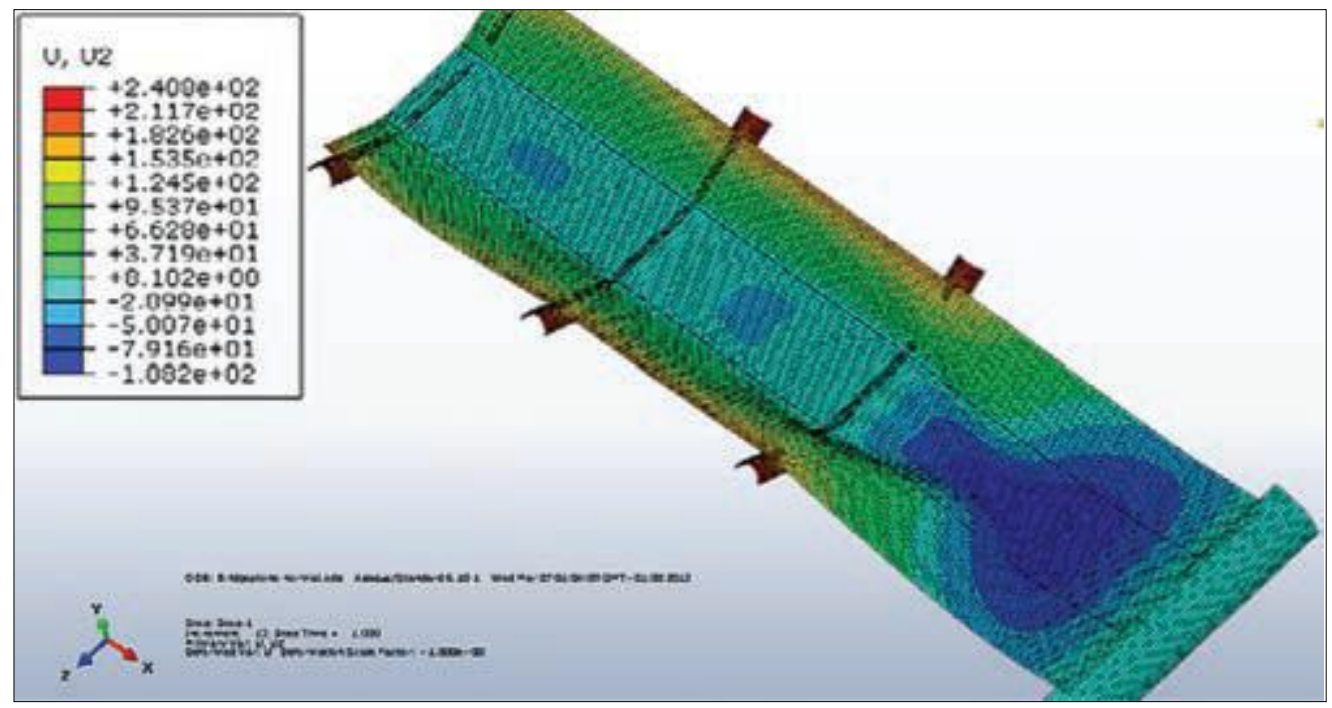

Fig. 2. Deformations of the conveyor belt [10]

\section{An innovative proposal for a method of testing the conveyor belt condition}

These methods of checking the condition of the conveyor belt have numerous disadvantages and limitations. The system literature does not describe a system that fully meets the expectations of the fourth industrial revolution, creating a comprehensive monitoring system. Therefore, research was undertaken to create an innovative research system with smart sensors with IT communication.

To propose a new solution, one must specify the conditions that the system should meet. Based on the analysis of the literature and knowledge of the state of the art, more important requirements can be identified for the system controlling the tension and condition of the conveyor belt. These are: reliable construction, adaptability to existing and operating belt conveyors, real-time data collection and analysis, speed of operation, accuracy and repeatability of measurements.

To create a research system that meets the requirements of devices in the era of Industry 4.0, a set of strain gauges was used. Their application in external systems collecting data directly during work from the entire surface of various types of belts is an innovative solution.

Fig. 3 shows a schematic diagram of the monitoring device built into the conveyor belt roller.

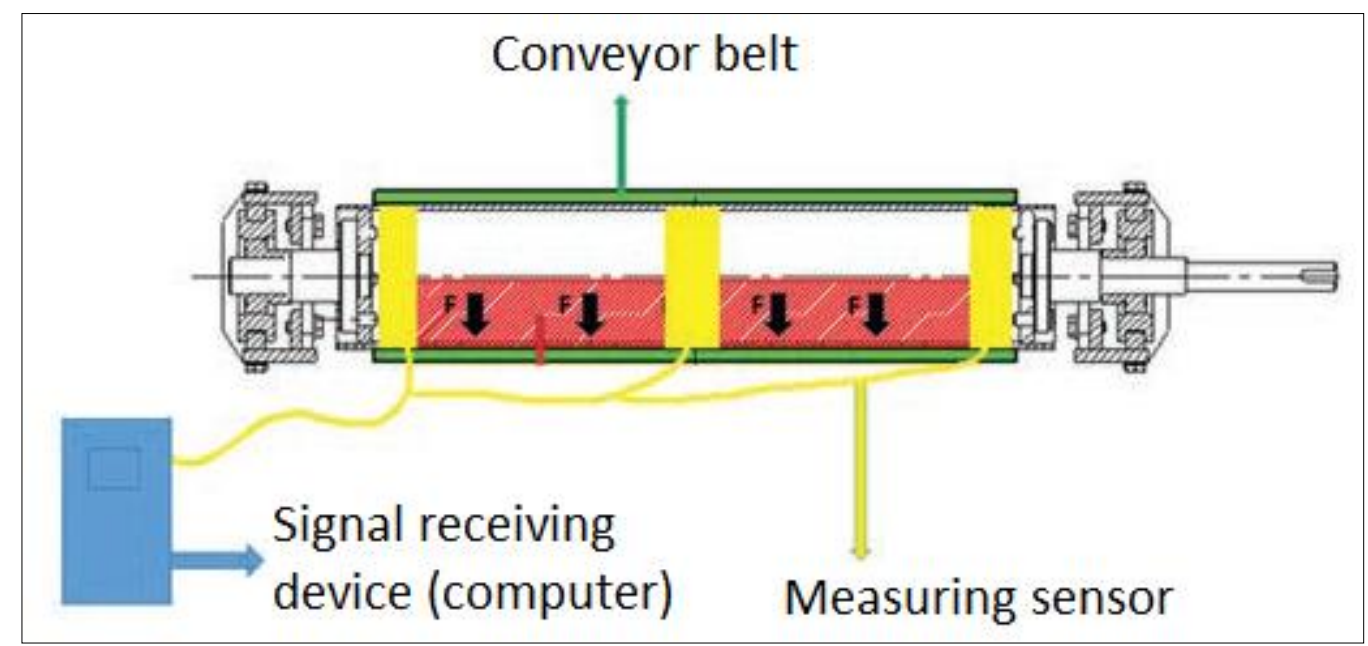

Fig. 3. Proposed device controlling the belt tension

It is important that real-time data show wear on the full surface of the belt, at almost every point. It is necessary to choose the reference state image that will be suitable for later processing and will provide a reliable result. 
From the analysis of the literature, it can be concluded that it is right to assume the pressure force of the belt $F[\mathrm{~N}]$ in a unit of time $t[\mathrm{~s}]$ as a quantity that, after proper processing and interpretation, can reveal any possible damage to the belt at an early stage or a final break. From the signal from the pressure force sensor located underneath the conveyor belt, a data set is obtained, from which a peak indicating changes in the surface of the belt can be recorded. Because the sensor acquires pressure data from its entire surface, it enables control of the belt over the entire width. In addition, to increase stability during measurement, the belt was loaded with a constant control mass, which indirectly exerts pressure on the sensor. Due to the additional load applied, the initial value was pre-set, the clearance in the measuring system was eliminated and the belt was pressed against the sensor along its entire width.

The system uses strain gauges that measure the pressure. Knowing the value of measurements, one can get the force that acts on the test system at a given point from formula (2):

$$
F=m \cdot g
$$

where: $F$ - force read from the sensor $[\mathrm{N}], \mathrm{g}$ - gravitational acceleration $\left[\mathrm{m} / \mathrm{s}^{2}\right], m-$ mass $[\mathrm{kg}]$ loading the sensor, exerting the force $F$.

The proposed monitoring system can be fully adapted to various conveyor designs and meet the requirements of Industry 4.0. A prototype of the research system is currently being monitored to control the condition of the conveyor belt in a real time.

\section{Summary}

Currently, the condition of the belt is analyzed using expensive and complex systems. Their use in industrial conditions requires significant modification of existing conveyors or the use of special belts. The proposed innovative research methodology is to provide data important for the process without significant interference in the current system, maintaining its usability, with little financial input.

\section{REFERENCES}

[1] Mazurkiewicz D. „Studium wybranych aspektów diagnostyki eksploatacyjnej transportu taśmowego”. Lublin: Politechnika Lubelska, 2011.

[2] Szulewski P. „Integracja informatyczna kluczowym aspektem środowiska wytwórczego w Przemyśle 4.0”. Mechanik. 8-9 (2018): 630-636, https://doi.org/10.17814/mechanik.2018.8-9.100.

[3] Gładysewicz L. „Przenośniki taśmowe teoria i obliczenia”. Wrocław: Oficyna Wydawnicza Politechniki Wrocławskiej, 2003.

[4] Kulinowski P. „Dobór mocy napędu i wytrzymałości taśmy przenośnika w warunkach pracy ustalonej”. www.kmg.agh.edu.pl/Dydaktyka/Przedmioty/Transport przenosnikowy/Materialy/PT algorytm.pdf.

[5] Żur T., Hardygóra M. „Przenośniki taśmowe w górnictwie”. Katowice: Wyd. Śląsk, 1996.

[6] Madziarz M. „Wpływ konstrukcji i technologii wykonywania połaczeń tkaninowych, wieloprzekładkowych taśm przenośnikowych na ich wytrzymałość". Rozprawa doktorska (niepublikowana). Wrocław: Politechnika Wrocławska, 1998.

[7] Błażej R. „Wpływ właściwości mechanicznych rdzenia taśm przenośnikowych tkaninowo-gumowych na wytrzymałość ich połaczeń". Rozprawa doktorska (niepublikowana). Wrocław: Politechnika Wrocławska, 2001.

[8] Nowak R., Grzyb K. „Monitoring i badania laboratoryjne w procesie diagnostyki taśm przenośnikowych z rdzeniem z linek stalowych”. Materiały XVI Międzynarodowego Sympozjum „100 lat w służbie polskiego przemysłu wydobywczego". Zakopane: FTT Stomil Wolbrom S.A., 2008: 39-54.

[9] Lutyński A. „O diagnozowaniu taśm przenośnikowych”. Prace Naukowe Instytutu Górnictwa Politechniki Wrocławskiej. 78 (1995).

[10] Fedorko G., Ivančo V. „Analysis of force ratios in conveyor belt of classic belt conveyor”. Procedia Engineering. 48 (2012): 123-128, https://doi.org/10.1016/j.proeng.2012.09.494. 